\title{
Treatment of Low-Strength Rubber Industry Wastewater Using a Combined Adsorbents and Membrane Technologies
}

Subriyer Nasir ( $\nabla$ subriyer@unsri.ac.id )

Universitas Sriwijaya

Elsa Rama Lumban Gaol

Universitas Sriwijaya Fakultas Teknik

Susi Susanti

Universitas Sriwijaya Fakultas Teknik

Meta Mediana

Universitas Sriwijaya Fakultas Teknik

Agung Mataram

Universitas Sriwijaya Fakultas Teknik

\section{Research}

Keywords: adsorbent, bentonite, calcium carbide residue, coal fly ash, hybrid membrane

Posted Date: November 25th, 2020

DOI: https://doi.org/10.21203/rs.3.rs-113449/v1

License: (9) This work is licensed under a Creative Commons Attribution 4.0 International License.

Read Full License 


\section{Abstract}

The discharge of liquid waste from rubber industry poses a significant threat to human beings and environment; therefore, it ought to be addressed. Meanwhile, activated sludge technologies are usually used in Indonesia by this industry to handle liquid waste and tackle discharge issues. The combined adsorbents and hybrid membrane UF/RO were proposed in this study to decrease contaminants parameter of rubber industry wastewater (RIW). Furthermore, to achieve this goal three steps of treatments were applied in the current experiment. The first step is filtration using sand filter columns containing silica sand and activated carbon. In addition, the second stage is categorized by adsorption using three types of adsorbents, namely calcium carbide residue (CCR), coal fly ash (CFA) and bentonite. The third stage is separation process using adsorbents and UF/RO. This investigation was conducted using three types of adsorbents arranged in series configuration followed by UF/RO.

Results showed that combined adsorbent (CCR-CFA-bentonite) followed by UF/RO membranes increases the acidity of RIW from 4.70 to 7.28 with removal efficiency of turbidity, chemical oxygen demand (COD), biological oxygen demand (BOD), total suspended solid (TSS), ammonia-nitrogen (AN), and total nitrogen (TN) at $99.0,88.1,92.5,89.5$, and $67.5 \%$, respectively.

The currently proposed method is advantageous because it does not require a long processing time or an intensive treatment area. This is applicable in rubber industries wastewater treatment process and is therefore an alternative method to active sludge technologies. In addition, final permeate RO are potentially used as clean water for rubber factory needs.

\section{Introduction}

Rubber trees (Hevea brasiliensis) are mainly cultivated in Southeast Asian countries especially Thailand, Indonesia, Vietnam, and Malaysia since the 19th century. These countries supply about 70 to $80 \%$ of the global natural rubber production. Furthermore, as second largest natural rubber producer worldwide, Indonesia supplied about $26 \%$ of natural rubber to the global market in 2013 . Meanwhile, due to the rapid industrial and economic development, some changes in land usage occurred in middle 1980's and therefore large plantation were converted for industrial, commercial, and residential uses. In addition, large quantities of wastewater are presently produced by rubber processing factories in Asia and Africa, this discharge to soil and water bodies poses a lot of environmental danger [1-5].

Moreover, processing of natural rubber consumes a large quantity of water, in addition to some chemicals. The considerable amount of wastewater generated along with effluents are toxic and equally have strong colors, low pH, high suspended solids, temperature, chemical oxygen demand (COD), and biological oxygen demand (BOD) [5]. These characteristics have increased the importance of treating raw rubber processing wastewater before being disposed into water bodies. The liquid waste from this activity do not only contain high organic substances, but high nitrogen pollutants as well [6]. These, liquid 
waste contains other components including organic matter especially sugar, protein, lipids, nitrogenous, and additional compounds specifically sulfates and heavy metals.

The conventional rubber industry wastewater (RIW) treatment facility needs a large processing area, due to time involved and odor factor. Furthermore, most factories have an open-type wastewater treatment systems due to the low operating costs and ease of maintenance [7]. Therefore, the environment ought to be protected through recycling and therefore a combination of two or more advanced treatment wastewater processes has been proposed [8-10]. The processing of RIW is currently done using conventional methods especially coagulation and ozonation [9], aerobic and anaerobic bacteria [11], adsorption and membrane technology [12-15]. This method has been replaced by membrane-based processes especially ultrafiltration (UF), nanofiltration (NF), and reverse osmosis (RO) which is known to be highly effective for water reclamation without consuming much chemicals.

A few studies to reduce the contaminant parameters of the RIW have notably been performed by researchers. The integration of NF membrane and evaporation technologies to treat rubber wastewater show that the use of retentate from NF has improved feed water and evaporators capacity with $55 \%$ reduced energy cost [8]. Meanwhile, application of aerobic granular sludge for RIW treatment was reported to have removal efficiencies of about $96.5 \%$ COD, $94.7 \%$ ammonia-nitrogen (AN) and $89.4 \%$ total nitrogen (TN) at the end of the granulation period [12]. Previous study have examined the treatment of RIW using pilot-scale up flow anaerobic sludge blanket (UASB) and downflow hanging sponge system combined with a baffled reactor in addition to settling tanks [14]. The results therefore indicated UASB reactors achieved a total removal efficiency of 39.0 to $72.2 \%$ for COD and 67.5 to $88.1 \%$ for BOD. In addition, the system proposed about $92 \%$ and $80 \%$ reduction of greenhouse gas emissions and hydraulic retention times respectively.

The application of direct contact membrane distillation in the RIW treated decreases total organic carbon (TOC), sulfate, color, turbidity, conductivity and TDS by almost $96 \%$ [16]. Previous study on the use of palm oil mill effluent (POME) for water reuse when combined with UF and RO membranes showed turbidity and $\mathrm{BOD}_{5}$ were reduced by about $99 \%$ and $98.9 \%$, respectively [17]. The final permeates of RO were noticed to comply with standards for water reuse. In addition, the combination of UF and RO method was concluded to be a viable alternative with great potential for use in palm oil industries.

A recent study shown when the RIW treated by sand filtration, cartridge filtration, UF, NF and then RO membranes successively produce the permeate was much better than biological treatment. The removal efficiencies of BOD and COD in this process exceeded $99 \%$, while TN and AN were leveled at $93 \%$ [10].

The adsorption method is equally a prevailing technique for removal of contaminants from liquid waste due to the simplicity and effectiveness in treatment of industrial effluents. The increased number of publications on adsorption of toxic compounds by adsorbents, is a sign of enhanced interest in synthesis of new low-cost adsorbents for water treatment [18-26]. 
CCR is a solid waste product from acetylene production and popularly used as a raw material for polyvinyl chloride (PVC) synthesis where 1.5-1.9 tons of CCR was obtained while manufacturing 1.0 ton of PVC. This by product is also released by welding processes and mainly comprises calcium hydroxide, a highly alkaline $(\mathrm{pH}>12)$ substance [20],[27].

Meanwhile, CFA is a particulate by-product generated from coal combustion in power plants and often used as a construction raw material [28] due to the residue's chemical and mineralogical composition. The compound is a cheap and abundant aluminosilicate source for producing valuable pollutant adsorbents including zeolites, catalysts, photo-catalysts, and geo-polymers. Many studies have also identified these substances as efficient and cost-effective alternatives to remove aqueous and gaseous pollutants, as well as for mercury adsorption [24], radioactive-isotope and rare element separation [27], geo-polymer synthesis [29], acid mine drainage treatment [30], coking wastewater treatment [31], and crude oil purification (32). Furthermore, related research disclosed these CFA based materials were potential wastewater remediation adsorbents and membrane filters [27].

Bentonite is a volcanic ash clay comprising mainly montmorillonite (a smectite crystal with two tetrahedral silica sheets and a central alumina octahedral layer structure). The mineral may be used as a sorbent in waste water treatment with or without prior modification [19]. These chemical alterations are possible due to the surface water molecules plus exchangeable cation interlayer configuration [33] and are applicable in heavy metal cationic exchange including copper, tin, cadmium, zinc, and iron removal [21].

Therefore, this study's purpose is to combine these adsorbents with sand filter and a hybrid membrane UF/RO to decrease effluent COD, BOD, TSS, AN, TN, and turbidity levels as well as to increase $\mathrm{pH}$ and RIW quality.

\section{Materials And Method \\ 2.1. Materials}

The main equipment for rubber industry wastewater treatment are sand filter (SF) and adsorbent columns with UF and RO membranes. A type 1054 fiber Reinforced Plastic (FRP) (fiber cylindrical tube with diameter 10 in and height 54 in) was used for SF and served as the adsorbents column. The SF column was filled by $45 \mathrm{~kg}$ of sand in the bottom and $10 \mathrm{~kg}$ active carbon on the top of column. Meanwhile, the UF module was a HM 90 commercial hollow fiber membrane (Molecular Weight Cut Off 50,000-150,000 DA and a $1 \mathrm{~m}^{2}$ active membrane area) and the RO module was a spiral wound membrane CSM (Korea) type RF 4021-TE (active membrane area of $3.3 \mathrm{~m}^{2}$ ) [30].

The RIW sample ( $\pm 6000 \mathrm{~L})$ was obtained from a South Sumatra rubber factory, Indonesia, then placed into five $1200 \mathrm{~L}$ polyethylene tanks and subsequently pumped into the sand filter and adsorbent columns at a constant flowrate $(5 \mathrm{~L} / \mathrm{min})$. 


\subsection{Method}

The RIW samples were pumped at a constant $5 \mathrm{~L} / \mathrm{min}$ feed rate into the SF, CCR, CFA and bentonite columns arranged in a serial configuration. These filtrates were then placed in separate $200 \mathrm{~L}$ polyethylene tanks. Subsequently, aliquots were collected with a beaker every fifteen minutes and analyzed. Furthermore, each adsorbent column output was fed to the UF and permeate was temporarily collected in the UF tank then pumped using RO high pressure pump to the RO membrane. The permeate from this process was collected at the reservoir tank, while the retentate was channeled into a $200 \mathrm{~L}$ plastic drum.

Figure 1 shows the columns' arrangement (CCR (4), CFA (5), and bentonite column (6), respectively). The results from this experiment were also compared with the wastewater treatment implemented in rubber factories including the active sludge, aerobic granular sludge, and anaerobic processes.

\section{Results And Discussion}

Table 1 shows the RIW sample characteristic, where the initial pH, COD, BOD, AN, and TN exceed the South Sumatra Governor Regulation No. 8/2012 permissible limits. However, these guidelines do not apply to turbidity, therefore the effluent was directly discharged into the river after all standard requirements were attained. The final COD content was observed to be lower than 10,000 mg/L) [8], hence, the RIW was categorized as low strength rubber wastewater.

Table 1

Rubber industry wastewater characteristics

\begin{tabular}{|llll|}
\hline Parameter & Units & Results & Standard \\
\hline $\mathrm{pH}$ & - & 4.7 & $6-9$ \\
\hline Turbidity & $\mathrm{NTU}$ & 268 & $\mathrm{n} . \mathrm{a}$ \\
$\mathrm{COD}$ & $\mathrm{mg} / \mathrm{L}$ & 350 & 200 \\
$\mathrm{BOD}$ & $\mathrm{mg} / \mathrm{L}$ & 280 & 60 \\
$\mathrm{TSS}$ & $\mathrm{mg} / \mathrm{L}$ & 125 & 100 \\
$\mathrm{NH}_{3}-\mathrm{N}$ & $\mathrm{mg} / \mathrm{L}$ & 9.5 & 5 \\
$\mathrm{TN}$ & $\mathrm{mg} / \mathrm{L}$ & 18.0 & 10 \\
\hline
\end{tabular}

\subsection{Effect of sand filter and adsorbents on performance 3.1.1. Acidity $(\mathrm{pH})$ of filtrates}


Figure 2 showed the effect of pretreatment time on the process, following the employment of SF, CCR, CFA, and bentonite in RIW pH alteration. The wastewater had an initial pH of 4.7 and increased to 6.5 after 90 minutes of operation due to the presence of active carbon in the SF column. The acidity was observed to increase slightly when CFAwas used as the adsorbent, and the resultant pH of the column filtrate was within the range of 6.5-6.8. In addition, several results were obtained with the employment of CCR as the adsorbent and basicity was noted to vary from 8.5 to 9.8 . The result revealed the greater $\mathrm{pH}-$ increasing power of CCR in comparison with bentonite and CFA. However, the values obtained exceeded the standard, and the rise in acidity was detected to be induced by the alkaline $(\mathrm{pH}>12)$ property of CCR attributable to a predominant composition with calcium hydroxide [34]. The existence of activated carbon in the sand filter column also promoted the adsorption of acidic anions from the feed and further synergized this reaction.

Figure 3 illustrated the $\mathrm{pH}$ of the UF and $\mathrm{RO}$ residues and filtrates following the use of combined adsorbents. The combination of CCR, CFA and bentonite were able to elevate the acidity of the deposits and filtrates as observed from the membranes and adsorbents. This occurred as the supply device was relatively free of contaminants comprising heavy metal ions, as well as anions including nitrates, nitrites, and sulfides.

The filtrates from the adsorptive mixture had a $\mathrm{pH}$ between 7.1 to 7.3 revealing the combination of CCR, CFA and bentonite performed suitably in the RIW acidity neutralization, and also influenced the compliance of the final permeate.

\subsubsection{Turbidity}

Turbidity refers to water or wastewater clarity evaluation prompted by the presence of suspended solids [35]. During membrane filtration, the dispersed particles initiate a flux decline in the membrane system [36], hence, pretreatment processes are necessary for cloudy liquids to prevent pollution and scaling on the membrane surface. The exclusion efficiency of pretreatment techniques and hybrid UF/RO on the RIW are displayed in Fig. 4, and the results demonstrated the capability of the SF to reduce the turbidity by 93$94.5 \%$ after a period of 90 minutes. The CCR, CFA, and bentonite columns therefore produced turbidity of $97 \%, 94.2 \%$ and $97.8 \%$, respectively, while approximately $99 \%$ was eliminated by UF and RO.

The procedures showing the adsorbent employment are displayed in a series configuration in Fig. 5 and Fig. 6. In these experiments, the filtrates were withdrawn from the column (6) (Fig. 1), and the removal efficiency of AN during the study was observed to be higher compared to each adsorbent.

\subsubsection{Chemical Oxygen Demand (COD)}

The COD was the major parameter considered in the wastewater treatment, and also represented the organic substances in the RIW. In addition, higher values were implicated in the production of odors, resulting from the low dissolved oxygen concentrations present in decomposing organic liquid waste matter. Figure 6 demonstrated the average COD removal efficiency to be $88.6 \%$ during CCR-UF/RO system use. This value was $89.3 \%$ while using the CFA-UF/RO method, and $>96 \%$ with the Bentonite-UF/RO 
system. The simultaneous use of the combined adsorbents and UF/RO effectively diminished this parameter from $350.2 \mathrm{mg} / \mathrm{L}$ to $22.8 \mathrm{mg} / \mathrm{L}$ (93.4\%).

\subsubsection{Biological Oxygen Demand $\left(\mathrm{BOD}_{5}\right)$}

The $\mathrm{BOD}_{5}$ signifies the amount of dissolved oxygen required by microbes, especially bacteria, to decompose organic matter under aerobic conditions. This phenomenon is an extensively applied factor for water quality assessment as information regarding the readily biodegradable organic fractions in water and wastewater are provided accordingly [37]. Figure 6 also showed the average BOD removal efficiency of CCR- UF/RO system to be $97.8 \%$. However, the BOD was lower when CFA was used, and the CFA-UF/RO and bentonite-UF/RO systems were detected to decrease the average BOD by $94.8 \%$ and $93.8 \%$ respectively. The application of both adsorbent mixtures with UF/RO therefore, effectively diminished this parameter from $280.2 \mathrm{mg} / \mathrm{L}$ to $6.8 \mathrm{mg} / \mathrm{L}(97.57 \%)$.

\subsubsection{Total suspended solids (TSS)}

The liquid waste from rubber industries contains high levels of TSS, and the effect of pretreatment using the sand filter and bentonite adsorbent columns on decreasing this component in RIW was shown in Fig. 6. The CCR, CFA, and bentonite modified the TSS values by $89.2,93.1$, and $97.6 \%$ consecutively, while the adsorbent blend followed by UF/RO depleted this parameter from $124.5 \mathrm{mg} / \mathrm{L}$ to $9.3 \mathrm{mg} / \mathrm{L}(92.5 \%)$. Meanwhile, the fairly diminished TSS efficiency was chiefly as a result of the adsorbent shielding by the suspended colloids in the sample.

\subsubsection{Ammonia-nitrogen $\left(\mathrm{NH}_{3}-\mathrm{N}\right)$}

Ammonia is implicated in several roles, including as a water pollutant, toxic substance, as well as a dangerous organic material. Therefore, high concentrations of AN in liquid waste triggers poisoning in the biota. The average quantity normally varies from 5 to $1000 \mathrm{mg} / \mathrm{L}$ in industrial wastewater and 10 to $200 \mathrm{mg} / \mathrm{L}$ in municipal liquid waste [38]. The initial strength of AN in the sample was $9.5 \mathrm{mg} / \mathrm{L}$, and this value exceeded the standard established by the Governor of South Sumatra regulation No. 8/2012. The removal efficiencies of CCR-UF/RO technique were $67,57.2$, and $55.8 \%$, respectively, and dissimilar results were obtained with CFA use. The removal efficiencies for CFA-UF/RO system were $87.4 \%, 98.4 \%$, and $99.6 \%$, while the bentonite-UF/RO system produced figures of $79.9 \%, 83.7 \%$, and $89.5 \%$, consecutively.

Figure 6 demonstrated the AN removal efficiency of $49.5 \%, 56.7 \%, 58.7 \%$ and $59.2 \%$, respectively following an increase in contact time. However, the removal efficiencies were observed to decline after 90 minutes. It is similar to study of Seruga et al (2019) that the highest adsorption capacity of ammonium ions with the maximum removal efficiency $(52.3 \%)$ was obtained for bentonite with a $0-0.05 \mathrm{~mm}$ particle size in $3 \mathrm{~h}$ of contact time [39]. Figure 6 also showed a decline in the average ammonia-nitrogen concentration from $9.5 \mathrm{mg} / \mathrm{L}$ to $3.4 \mathrm{mg} / \mathrm{L}(64.2 \%)$ produced by the application of the adsorbent combination and UF/RO.

\subsubsection{Total Nitrogen}


TN concentration is one of the parameters known to affect water quality. Therefore, the removal is referred to as nitrification and denitrification in the wastewater treatment plant, including RIW where the activated sludge process is applied. The method termed eutrophication is known to reduce the effect of nitrogen compound in the water bodies. Figure 6 . shows the outcome of pretreatment using sand filter and bentonite adsorbent column to decrease the TN. Furthermore, the efficiency for CCR-UF-RO systems were $72.1,94.4$, and $94.4 \%$, respectively. These figures increase with the use of CFA as an adsorbent. The corresponding efficiency values were $88.9,91.1$, and $97.8 \%$. However, bentonite-UF/RO system decreased the value to $76.1,80.6,94.4 \%$ respectively, while the TN reduced from $18 \mathrm{mg} / \mathrm{L}$ to $5.9 \mathrm{mg} / \mathrm{L}(67.5 \%)$ for the combined adsorbent.

\subsubsection{Comparison with other processes}

The RIW sample in the current experiment was provided by a rubber factory where the active sludge process was employed during liquid waste treatment. Table 2 illustrated a comparison between the present method and other treatment processes.

\section{Table 2.}

Removal efficiencies comparison of the combined adsorbents-UF/RO and another rubber wastewater treatment processes

\begin{tabular}{|c|c|c|c|c|c|c|c|}
\hline Parameter & $\mathrm{pH}$ & Turbidity & COD & BOD & TSS & AN & $\mathrm{TN}$ \\
\hline Processes & & $(\%)$ & (\%) & (\%) & (\%) & (\%) & (\%) \\
\hline Adsorbents/ UF/RO & 7.28 & 99.0 & 93.5 & 97.6 & 92.5 & 64.2 & 67.5 \\
\hline \multicolumn{8}{|l|}{ Active Sludge $^{a}$ ) } \\
\hline . January & 6.70 & n.a & 91.5 & 95.9 & 91.8 & 84.6 & 86.4 \\
\hline July & 6.63 & n.a & 87.9 & 94.4 & 79.1 & 83.7 & 80.8 \\
\hline - $\quad$ August & 6.60 & n.a & 87.7 & 97.5 & 92.2 & 57.8 & 82.4 \\
\hline . $\quad$ September & 6.03 & n.a & 92.0 & 93.8 & 95.7 & 86.2 & 87.1 \\
\hline . $\quad$ October & 6.53 & n.a & 82.3 & 82.7 & 70.0 & 83.1 & 94.7 \\
\hline . $\quad$ November & 6.01 & n.a & 94.5 & 96.6 & 86.3 & 90.4 & 88.9 \\
\hline Average & 6.41 & n.a & 89.3 & 93.5 & 85.8 & 80.9 & 86.7 \\
\hline Microphyte pond ${ }^{\mathrm{b}}$ ) & n.a & n.a & 85.5 & 90.6 & n.a & n.a & n.a \\
\hline UASB upflow anaerobic sludge blanket ${ }^{\mathrm{C}}$ ) & n.a & n.a & 72 & 90.1 & 98 & n.a & 82 \\
\hline Aerobic granular sludge ${ }^{d}$ ) & n.a & n.a & 96.5 & n.a & n.a & 94.7 & 89.4 \\
\hline Bioremediation with Athrobacter. $\mathrm{sp}^{\mathrm{e}}$ ) & n.a & n.a & 79.4 & 72.1 & 75.7 & 71.3 & n.a \\
\hline
\end{tabular}


a) average after six months of monitoring (January, July-November 2018). b) Owamah et al. (2015), c) Watari et.al (2016), d) Rosman et. al., (2013) e) Smitha et.al., (2012).

Furthermore, the conclusions derived from Table 2 showed the ability for adsorbents combined with UF and $\mathrm{RO}$ membranes to increase $\mathrm{pH}$ and reduce various RIW parameters. This proposed method has an advantage compared to the active sludge technology applied by most rubber industries in Indonesia, to ensure high removal of COD, BOD, TSS concentration. Consequently, filtrates are produced more clearly for utility in the internal needs of rubber factories, despite the lower removal efficiency of AN and TN.

\subsection{Scanning electron microscope of adsorbents}

\subsubsection{Calcium carbide residue}

The pores structure needs to be examined with SEM in attempts to explore the morphology of adsorbent surface.

Figure 7a illustrates CCR images at 10100x of magnification and Fig. 7b shows the SEM images of raw CCR with pore diameter between 0.39-0.86 $\mu \mathrm{m}$. The residue contains aluminum, silicon, calcium, magnesium, and some metal oxide impurities, consisting of copper, potassium, titanium and barium. In addition, calcium is possibly identified in the form of $\mathrm{Ca}(\mathrm{OH})_{2}$ and $\mathrm{CaCO}_{3}$, known to be the main chemical component of CCR, while silicon, aluminum, and magnesium always appeared together. These existed in the form of silicates, including $\mathrm{Al}_{2} \mathrm{SiO}_{5}$ and $\mathrm{MgSiO}_{3}$ [20]. Also, EDS spectrum showed the existence of sulfur compounds on the adsorbent surface after adsorption. This suggested the presence of sulfur compounds in the rubber wastewater is the result from a highly organic compound or protein retained in the latex processing, characterized by the rotten-egg smell. Therefore, CCR has the potential to remove odor caused by these chemicals in the wastewater. The EDS spectra in Fig. 8a and Fig. 8b, show raw CCR contain $82 \% \mathrm{CaO}$ and $18 \% \mathrm{Sb}_{2} \mathrm{~S}_{3}$. Also, the presence of $\mathrm{Sb}_{2} \mathrm{~S}_{3}$ probably results from the welding process and other mechanical activities in the CCR sample location.

Figure $9 \mathrm{a}$ and $9 \mathrm{~b}$ show the SEM images of bentonite at 10100x magnification reflect the morphological solid and dark-shape with a particle surface area between $5251.8 \mu \mathrm{m}$ and $6503.9 \mu \mathrm{m}$. Figure 10a and Fig. $10 \mathrm{~b}$ also illustrate the highest average content of EDS before and after use, comprising elements of silicon, aluminum, carbon and iron. 
Table 3

Bentonite compounds before and after adsorbing the cation from the RIW

\begin{tabular}{|lll|}
\hline Compound & $\begin{array}{l}\text { Raw bentonite } \\
\text { (\% mass) }\end{array}$ & $\begin{array}{l}\text { Adsorbed bentonite } \\
\text { (\%mass) }\end{array}$ \\
\hline $\mathrm{SiO}_{2}$ & 55.60 & 62.57 \\
\hline $\mathrm{Al}_{2} \mathrm{O}_{3}$ & 28.92 & 25.56 \\
\hline $\mathrm{MgO}$ & 2.06 & 2.40 \\
\hline $\mathrm{CaO}$ & 3.07 & 1.52 \\
\hline $\mathrm{Fe}_{2} \mathrm{O}_{3}$ & 1.98 & 5.39 \\
\hline $\mathrm{Na}_{2} \mathrm{O}$ & 0.32 & - \\
\hline $\mathrm{O}_{2} \mathrm{~F}$ & 5.64 & - \\
\hline $\mathrm{ClO}_{3}{ }^{-}$ & 0.06 & - \\
\hline $\mathrm{K}_{2} \mathrm{O}$ & 1.89 & 1.10 \\
\hline $\mathrm{TiO}_{2}$ & 0.03 & 1.46 \\
\hline $\mathrm{CoO}^{2}$ & 1.42 & - \\
\hline
\end{tabular}

Table 3 shows the bentonite compound characteristics before and after cation adsorption from RIW. This indicates the raw form is dominated by silica, alumina, and iron with other impurities, encompassing magnesium, calcium, sodium, titanium, cobalt and potassium. Also, the substance is a nonmetallic clay mineral based on montmorillonite, while the lamellar structure of the crystal cell contains some cations, including $\mathrm{Cu}^{2+}, \mathrm{Mg}^{2+}, \mathrm{Na}^{+}, \mathrm{K}^{+}$, etc. However, bentonite properly performs cationic contaminant adsorption by an exchange mechanism, because the particles are very unstable and easily replaced [21]. The EDS chromatogram of the compound demonstrates the cationic substitution of silicon, aluminum, and magnesium with those of the RIW.

\subsubsection{Coal fly- ash}

CFA is applied either directly or indirectly to adsorb heavy metals, along with organic and inorganic pollutants from wastewater. These contaminants include phosphorus, fluorides, boron, phenolic compounds, pesticide, dyes etc. CFA is usually categorized into high ( $\geq 10 \% \mathrm{CaO}$ ) and low calcium fly ash ( $\leq 10 \% \mathrm{CaO})$ according to the $\mathrm{CaO}$ content [23]. Increased adsorption capacity of this substance is related to a large surface area, pore volume, porosity and an elevated unburnt carbon content. The 
morphology of CFA in Fig. 11a showed the presence of adhered superficial fragments indicating the competency as an adsorbent.

Fig,11b showed the SEM images of cenospheres, an important coal fly ash fraction. These CFA components are a mixture of aluminosilicate glasses with mullite and quartz crystalline phases [40]. The coal particles were noted to have experienced an acidic attack from compounds with pH of 4.7 in the RIW, capable of reacting with silicon and aluminum linkages contained in the CFA as the bond ratios are close to 1. Cenospheres are majorly composed of silica, alumina and iron oxides, and are extensively used due to the possession of unique properties including sphericity, inertness, lower densities than water, alongside water-resistance. Intensifications in the CFA surface aluminum concentration indicated the continuous use of alum instead of formic acid by numerous rubber farmers in South Sumatra, for the latex freezing process prior to factory transfer.

Table 4.

Energy Dispersive X-Ray of CFA

\begin{tabular}{|lll|}
\hline Element & Raw CFA (\%) & Adsorbed CFA (\%) \\
\hline $\mathrm{SiO}_{2}$ & 54.41 & 3.06 \\
$\mathrm{Al}_{2} \mathrm{O}_{3}$ & 39.57 & 67.36 \\
$\mathrm{NaO}_{2}$ & 3.32 & 11.64 \\
$\mathrm{MgO}$ & 0.41 & 4.84 \\
$\mathrm{BaO}$ & 0.32 & - \\
\hline $\mathrm{F}_{2} \mathrm{O}$ & 0.93 & - \\
\hline $\mathrm{SeO}$ & 0.01 & - \\
\hline $\mathrm{In}_{2} \mathrm{O}_{3}$ & 0.53 & - \\
\hline $\mathrm{TiO}_{2}$ & 0.50 & - \\
\hline $\mathrm{Fe}_{2} \mathrm{O}_{3}$ & - & 10.20 \\
\hline $\mathrm{K}_{2} \mathrm{O}$ & - & 3.07 \\
\hline
\end{tabular}

Table 4 showed the predominance of CFA contents by aluminum and silica and the presence of these elements were detected to increase the sensitivity of the residues to decreasing sample COD, BOD, TSS, AN, as well as TN by cationic exchange. The adsorbed CFA illustrated surges in oxygen and carbon percentages owing to organic substance absorption from the waste. According to [41], the solute binds to silanol (Si-O) groups from silica and $\mathrm{OH}$ groups from Al and Fe. Conversely, this value decreases for Al as 
a result of the amphoteric nature, hence, the element functions as a base under acidic condition sand increases the $\mathrm{pH}$ of the solution. CFA was therefore presumed to be useful as an adsorbent for wastewater treatment [42].

\section{Conclusions}

The decontamination of rubber industry wastewater through the use of sand filters in combination with three forms of adsorbents namely calcium carbide residue, bentonite, and coal fly ash followed by UF/RO membrane revealed the ability of these components to reduce the significant impurities present in the fluids to be processed.

1. Calcium carbide residue had a removal efficiency comprising $41.1 \%$ COD, $41.3 \%$ BOD, $22.9 \%$ TSS, $47.4 \% \mathrm{AN}$, and $94.4 \% \mathrm{TN}$, respectively. The filtrates from the residue produced $\mathrm{pH}$ values ranging from 8.5 to 9.5 .

2. Bentonite column generated the removal efficiencies of $97 \%$ COD, $98.5 \%$ BOD, $97.3 \%$ TSS, $98.5 \%$ AN, $94.4 \% \mathrm{TN}$, and $88.7 \%$ turbidity, respectively and increased the acidity of the rubber industry wastewater from 4.7 to 6.9 .

3. Coal fly ash had a removal efficiency of $99.2 \%$ COD, $98.9 \%$ BOD and $97.4 \%$ TSS, $99.8 \%$ AN, $97.7 \%$ $\mathrm{TN}$, and $99 \%$ turbidity, respectively. The filtrate from the coal fly ash column had an approximate $\mathrm{pH}$ of 7 .

4. The adsorbent combination together with UF/RO were able to cause reductions of $93.5 \%$ COD, $97.6 \%$ BOD, $92.5 \%$ TSS, $64.2 \%$ AN, $67.5 \%$ TN, along with $99 \%$ turbidity, and a consecutive increase in the acidity from 4.7 to 7.2 of the liquid waste.

Overall, the pilot scale designed for the treatment of RIW with the use of sand filters, adsorbent mixtures, and UF/RO employment is applicable in the acidity enhancement and contaminant depletion of rubber industry wastewater. All the adsorbents used were able to increase RIW acidity and the final RO filtrates accomplished water reuse standards.

\section{Declarations}

\section{AVAILABILITY OF DATA}

The data used to support the findings of this study are available from the corresponding author upon request.

\section{COMPETING INTEREST}

The authors declare that they have no competing interests

\section{FUNDING}


The author (SN) wish to acknowledge the Institute of Research and Community Service (LPPM) Universitas Sriwijaya funded through the Hibah Penelitian Profesi No: 007/UN9/SK.LP2M.PT/2018

\section{AUTHORS CONTRIBUTION}

Conceptualization and design of experimental, S.N., E.R.L.G., S.S., A.M., Collected the sample and data S.N., E.R.L.S., S.S., M.M., SN writing-original draft preparation, S.N., A.M. writing-review and editing, funding acquisition S.N.,

\section{ACKNOWLEDGMENT}

The authors wish to acknowledge the Institute of Research and Community Service (LPPM) Universitas Sriwijaya funded through the Hibah Penelitian Profesi, as well as PT. Hevea MK II Crumb Rubber Industries for the sample provision.

\section{References}

1. Vongkhamheng C, Zhou J, Beckline M, Phimmachanh S. Socioeconomic and Ecological Impact Analysis of Rubber Cultivation in Southeast Asia. Open Access Lib. 2016; 3:1-11

2. Owamah HI, Enaboifo MA, Izinyon OC. Treatment of wastewater from raw rubber processing industry using water lettuce macrophyte pond and the reuse of its effluent as biofertilizer. Agric Water Manag. 2015;146:262-69

3. Lumban Gaol ER, Nasir S, Hermansyah H, Mataram A. Rubber Industry Wastewater Treatment Using Sand Filter, Bentonite and Hybrid Membrane (UF-RO). Sriwijaya J Environ. 2019;4:14-18

4. Susanti S, Nasir S, Hermansyah H, Mataram A. Treatment of Wastewater from Rubber Industry Using Calcium Carbide Residue Adsorbent and Hybrid Membrane UF - RO. Sriwijaya J. Environ. 2019;37-41

5. Fong YC, Khin AA, Lim CS. Conceptual Review and the Production, Consumption and Price Models of the Natural Rubber Industry in Selected ASEAN Countries and World Market. Asian J Econ Model. 2018; 6:403-18

6. Yang X, Sheridan S, Ding L, Wang DK, Smart S, Diniz da Costa JC, et al. Inter-layer free cobalt-doped silica membranes for pervaporation of ammonia solutions. J Memb Sci. 2018;553:111-16

7. Tanikawa D, Syutsubo K, Watari T, Miyaoka Y, Hatamoto M, lijima S, et al. Greenhouse gas emissions from open-type anaerobic wastewater treatment system in natural rubber processing factory. J Clean Prod. 2016;119;32-37

8. Xin G, Lopes MP, Crespo JG, Rusten B. A continuous nanofiltration + evaporation process for high strength rubber wastewater treatment and water reuse. Sep Purif Technol. 2013;119:19-27

9. Massoudinejad M, Mehdipour-Rabori M, Dehghani MH. Treatment of natural rubber industry wastewater through a combination of physicochemical and ozonation processes. J Adv Environ Heal Res. 2015;3: 242-49 
10. Jiang SK, Zhang GM, Yan L, Wu Y. Treatment of natural rubber wastewater by membrane technologies for water reuse. Membr Water Treat. 2018;9:17-21

11. Visa M, Bogatu C, Duta A. Simultaneous adsorption of dyes and heavy metals from multicomponent solutions using fly ash. Appl Surf Sci. 2010; 256:5486-91

12. Rosman NH, Nor Anuar A, Othman I, Harun H, Sulong MZ, Elias SH, et al. Cultivation of aerobic granular sludge for rubber wastewater treatment. Bioresour Technol. 2013;133:630-34

13. Watari T, Mai TC, Tanikawa D, Hirakata Y, Hatamoto M, Syutsubo K, et al. Performance evaluation of the pilot scale upflow anaerobic sludge blanket - Downflow hanging sponge system for natural rubber processing wastewater treatment in South Vietnam. Bioresour Technol. 2017; 237:204-12

14. Watari T, Thanh NT, Tsuruoka N, Tanikawa D, Kuroda K, Huong NL, et al. Development of a BR-UASBDHS system for natural rubber processing wastewater treatment. In: Environmental Technology (United Kingdom). 2016;37:459-65

15. Ejraei A, Aroon MA, Ziarati Saravani A. Wastewater treatment using a hybrid system combining adsorption, photocatalytic degradation and membrane filtration processes. J Water Process Eng. 2019;28:45-53

16. Mokhtar NM, Lau WJ, Ismail AF, Veerasamy D. Membrane distillation technology for treatment of wastewater from rubber industry in Malaysia. In: Procedia CIRP. 2015: 26 : 792-96

17. Azmi NS, Md Yunos KF, Baharuddin AS, Dom ZM. The effect of operating parameters on ultrafiltration and reverse osmosis of palm oil mill effluent for reclamation and reuse of water. BioResources. 2013;8:76-87.

18. Pandey S. A comprehensive review on recent developments in bentonite-based materials used as adsorbents for wastewater treatment. Journal of Molecular Liquids. 2017;41:1091-113

19. Alexander JA, Ahmad Zaini MA, Surajudeen A, Aliyu ENU, Omeiza AU. Surface modification of lowcost bentonite adsorbents-A review. Particulate Science and Technology. 2019;37:538-49

20. Yang H, Cao J, Wang Z, Chen H, Gong X. Discovery of impurities existing state in carbide slag by chemical dissociation. Int J Miner Process. 2014;130:66-73

21. Huang Z, Li Y, Chen W, Shi J, Zhang N, Wang X, et al. Modified bentonite adsorption of organic pollutants of dye wastewater. Mater Chem Phys. 2017;202:266-76

22. Durán E, Bueno S, Hermosín MC, Cox L, Gámiz B. Optimizing a low added value bentonite as adsorbent material to remove pesticides from water. Sci Total Environ. 2019;672:743-51

23. Ge JC, Yoon SK, Choi NJ. Application of Fly Ash as an adsorbent for removal of air and water pollutants. Appl Sci. 2018;8:1116

24. Attari M, Bukhari SS, Kazemian H, Rohani S. A low-cost adsorbent from coal fly ash for mercury removal from industrial wastewater. J Environ Chem Eng. 2017;5:391-99

25. Ahmaruzzaman M. A review on the utilization of fly ash. Progress in Energy and Combustion Science. 2010;36:327-63 
26. Pourabbas Bilondi M, Toufigh MM, Toufigh V. Using calcium carbide residue as an alkaline activator for glass powder-clay geopolymer. Constr Build Mater 2018;183:417-28

27. Gollakota ARK, Volli V, Shu C-M. Progressive utilisation prospects of coal fly ash: A review. Sci Total Environ. 2019;672:951-89

28. Xing Y, Guo F, Xu M, Gui X, Li H, Li G, et al. Separation of unburned carbon from coal fly ash: A review. Powder Technology. 2019;353:372-84.

29. Eliche-Quesada D, Sandalio-Pérez JA, Martínez-Martínez S, Pérez-Villarejo L, Sánchez-Soto PJ. Investigation of use of coal fly ash in eco-friendly construction materials: fired clay bricks and silicacalcareous non fired bricks. Ceram Int. 2018;44:4400-12

30. Nasir S, Ibrahim E, Arief AT. Design and experimental testing of small-scale acid mine drainage treatment plant. J Mater Environ Sci. 2016;7:3004-10.

31. Wang N, Zhao Q, Xu H, Niu W, Ma L, Lan D, et al. Adsorptive treatment of coking wastewater using raw coal fly ash: Adsorption kinetic, thermodynamics and regeneration by Fenton process. Chemosphere. 2018;210:624-32

32. Adams F V., Peter A, Joseph I V., Sylvester OP, Mulaba-Bafubiandi AF. Purification of crude oil contaminated water using fly ash/clay. J Water Process Eng. 2019;30:100471

33. Ma J, Qi J, Yao C, Cui B, Zhang T, Li D. A novel bentonite-based adsorbent for anionic pollutant removal from water. Chem Eng J. 2012; 200-202:97-103

34. Altiner M. Use of Taguchi approach for synthesis of calcite particles from calcium carbide slag for CO 2 fixation by accelerated mineral carbonation. Arab J Chem. 2019;12: 531-40

35. Castaño JA, Higuita JC. Using turbidity for designing water networks. J Environ Manage. 2016;172:129-35

36. Chen $Y, X u$ W, Zhu H, Wei D, He F, Wang D, et al. Effect of turbidity on micropollutant removal and membrane fouling by MIEX/ultrafiltration hybrid process. Chemosphere. 2019;216:488-98

37. Jouanneau S, Recoules L, Durand MJ, Boukabache A, Picot V, Primault Y, et al. Methods for assessing biochemical oxygen demand (BOD): A review. Water Research. 2014; 49C:62-82

38. Ashrafizadeh SN, Khorasani Z. Ammonia removal from aqueous solutions using hollow-fiber membrane contactors. Chem Eng J. 2010;162:242-9

39. Seruga P, Krzywonos M, Pyzanowska J, Urbanowska A, Pawlak-Kruczek H, Niedźwiecki Ł. Removal of ammonia from the municipal waste treatment effuents using natural minerals. Molecules. 2019;24:20

40. Żyrkowskia M J. Rui Costa Neto, Luis F.Santos, Karol Witkowskic. Characterisation of fly-ash cenospheres from coal-fired power plant unit. Fuel. 2016;174:49-53

41. Shakhapure J, Vijayanand $\mathrm{H}$, Basavaraja S, Hiremath V, Venkataraman A. Uses of a-Fe $\mathrm{F}_{2} \mathrm{O}_{3}$ and fly ash as solid adsorbents. Bull Mater Sci. 2005; 28:713-18

42. Hosseini Asl SM, Javadian H, Khavarpour M, Belviso C, Taghavi M, Maghsudi M. Porous adsorbents derived from coal fly ash as cost-effective and environmentally-friendly sources of aluminosilicate 
for sequestration of aqueous and gaseous pollutants: A review. Journal of Cleaner Production. 2019; 208:1131-47

\section{Figures}

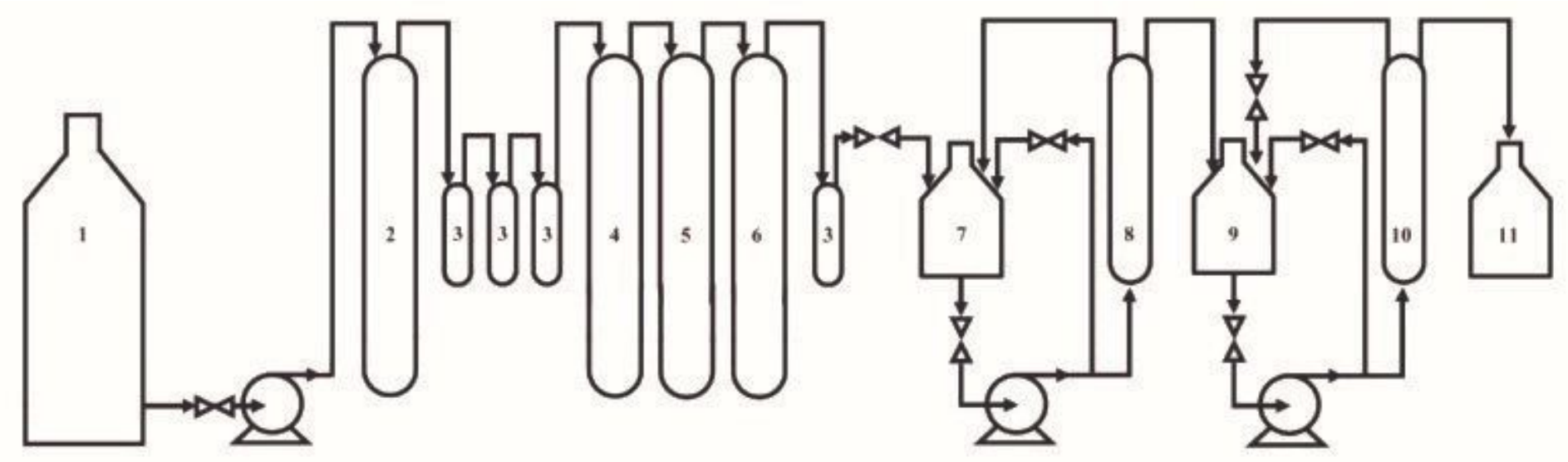

Figure 1

Wastewater treatment of rubber industry experimental set-up (1. The RIW tank 2. Sand filter column 3. Filter spoon 4. CCR column 5. CFA column 6. Bentonite column; 7. Storage tank 8. Ultrafiltration membrane module 9. Ultrafiltration storage tank; 10. Reverse osmosis module 11. RO permeate tank).

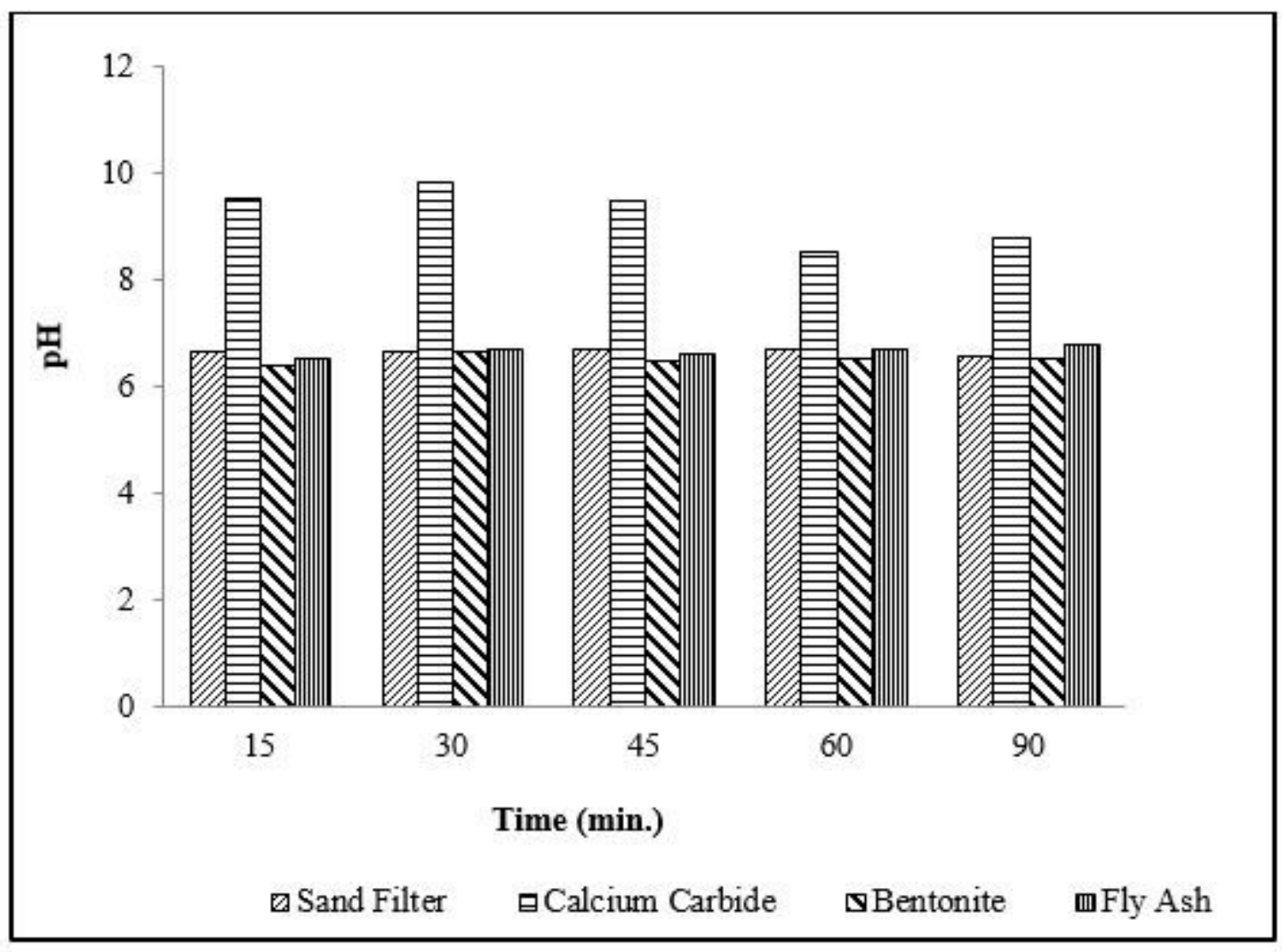

Figure 2 


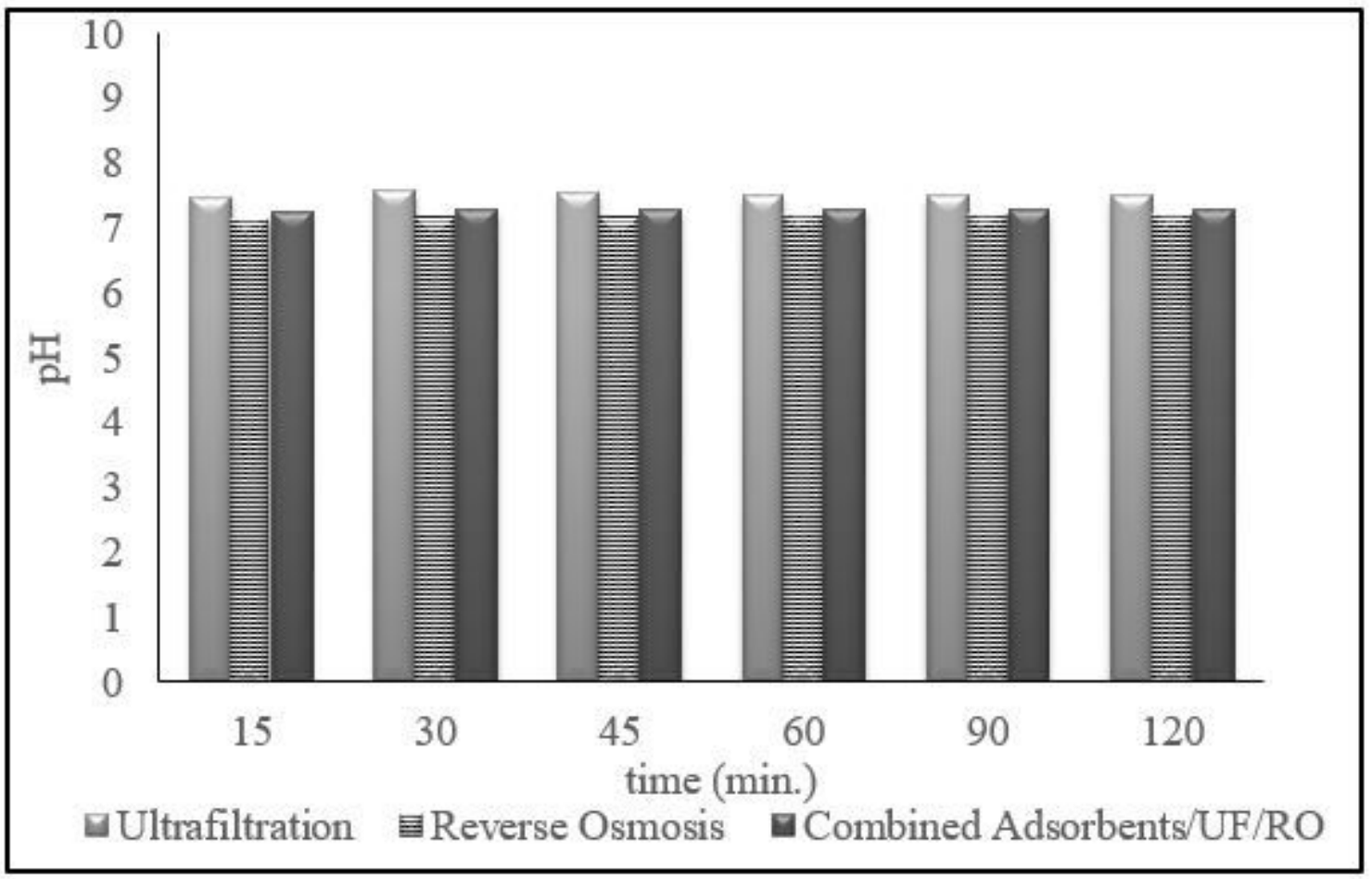

Figure 3

Change in $\mathrm{pH}$ for membranes and combined adsorbent

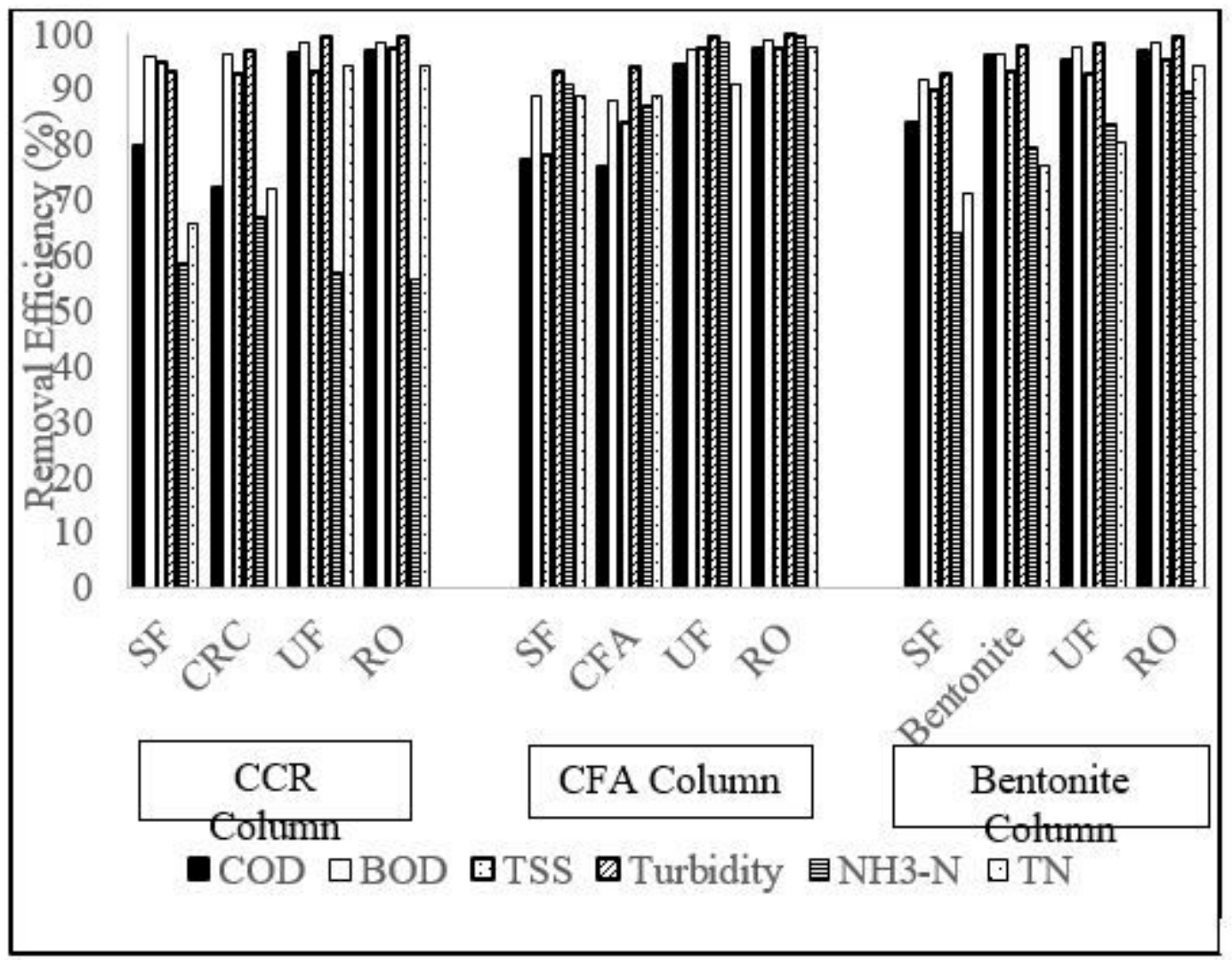


Figure 4

Removal efficiency of processes

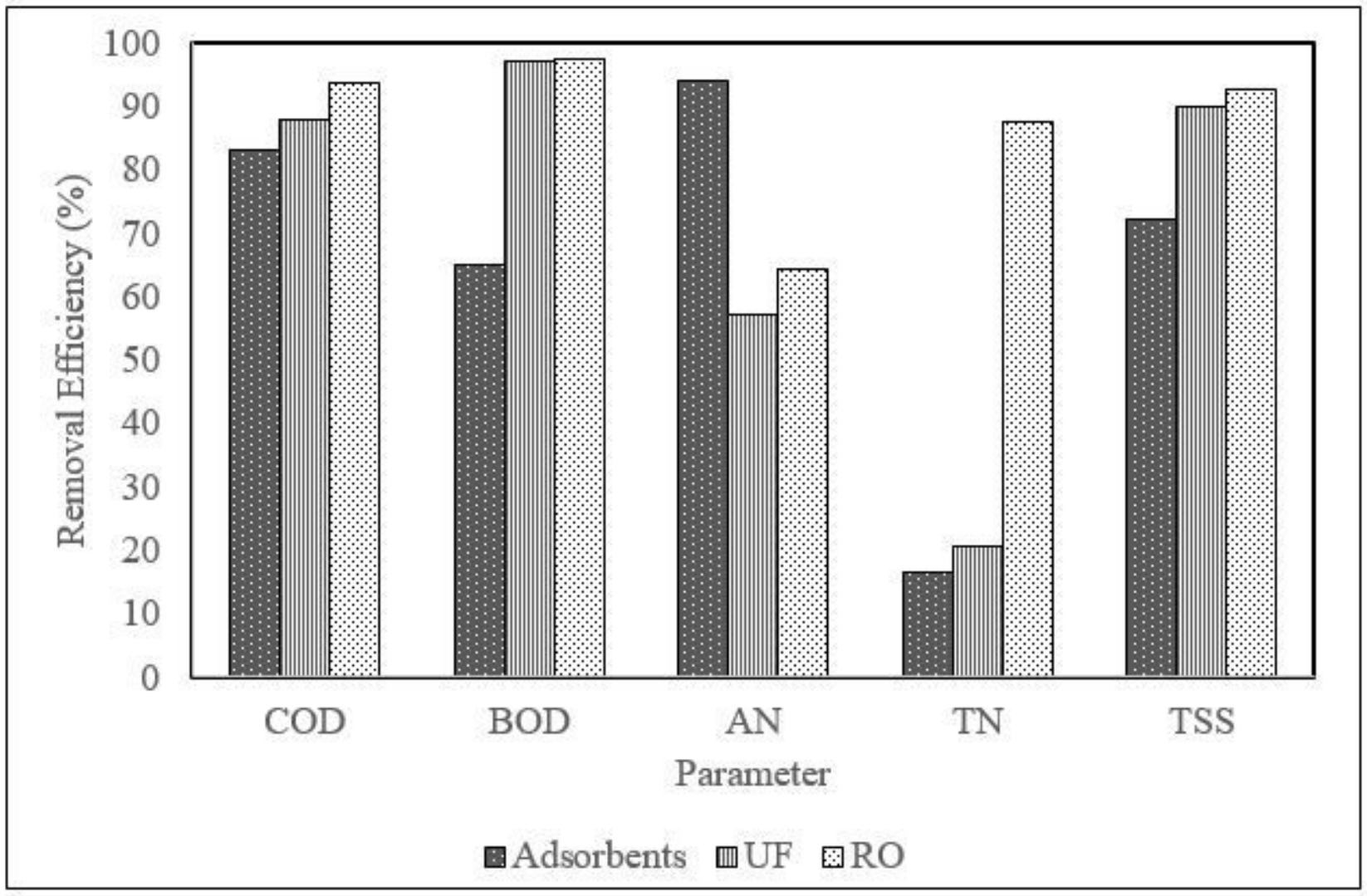

Figure 5

Removal efficiency of combined adsorbents, ultrafiltration, and reverse osmosis 


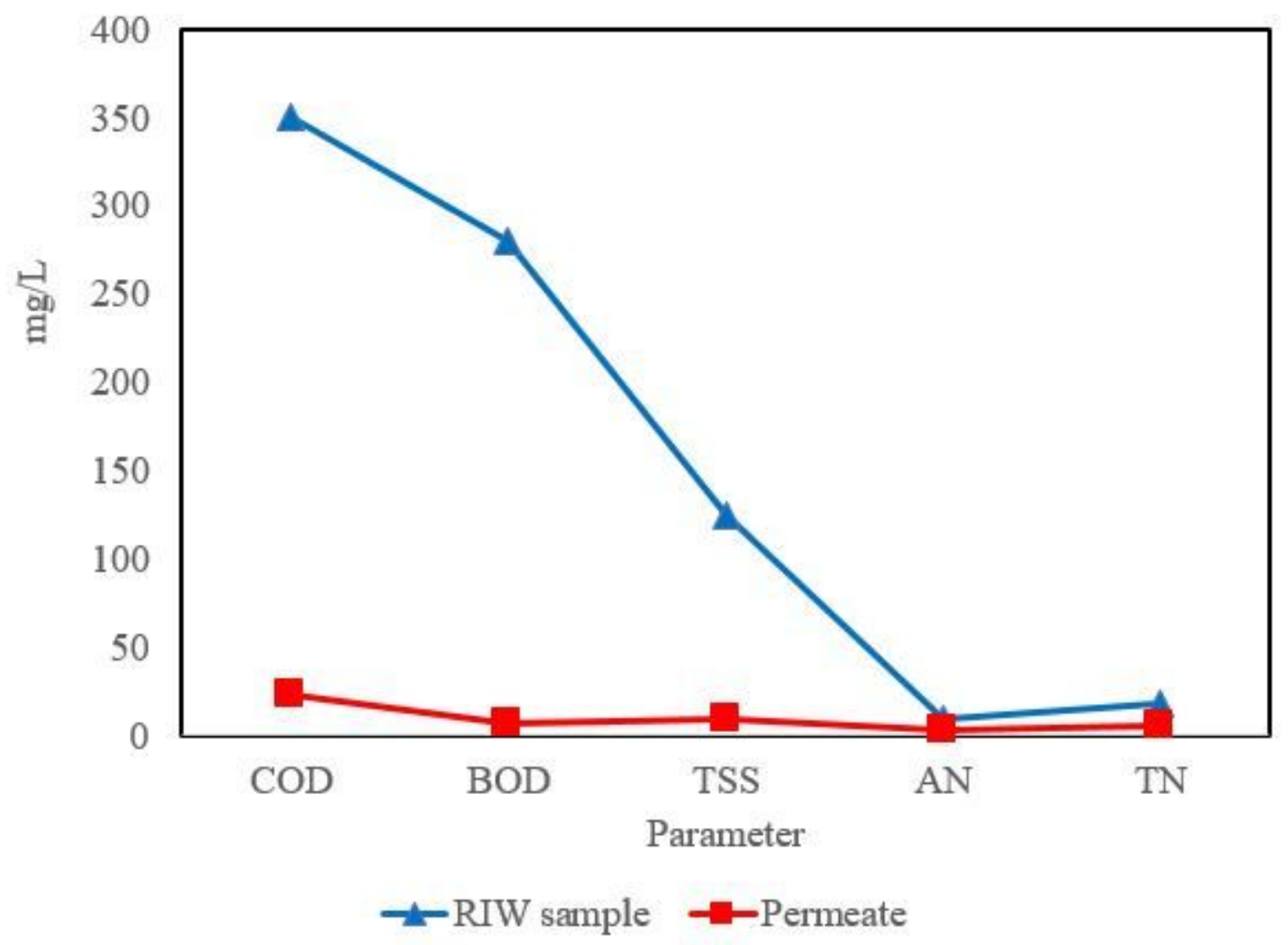

Figure 6

Change of the RIW parameter of combined adsorbents-UF and RO 


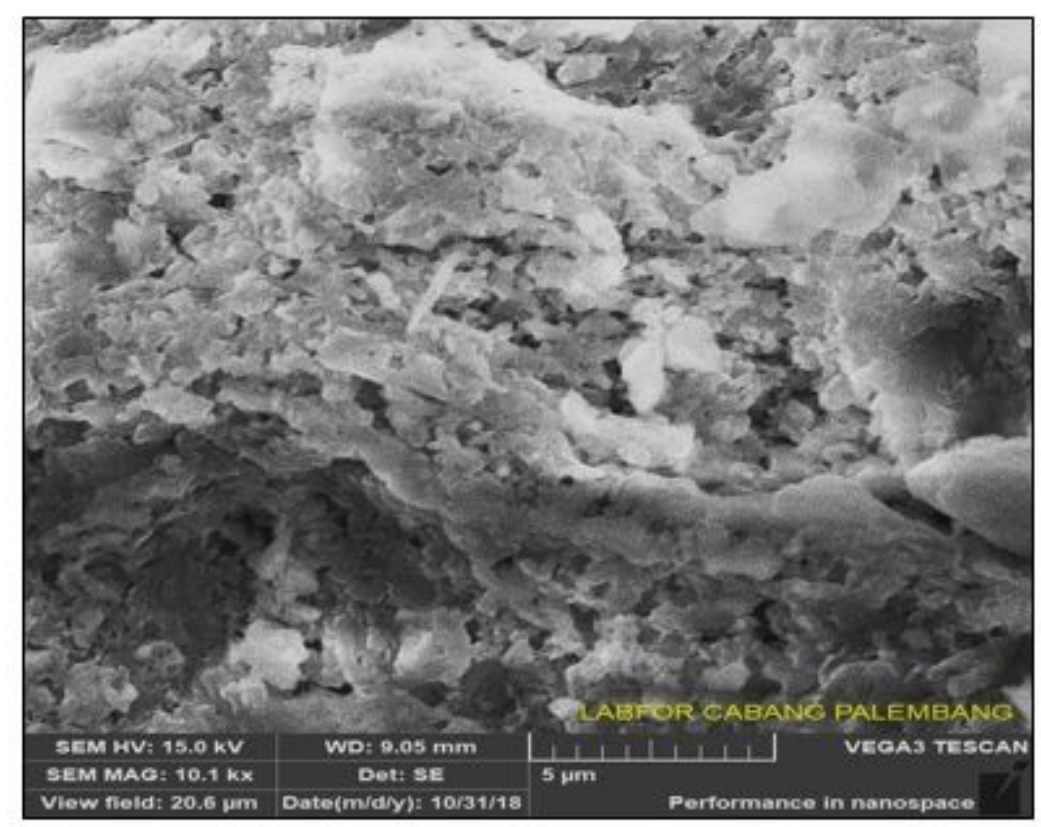

\section{$7 a$}

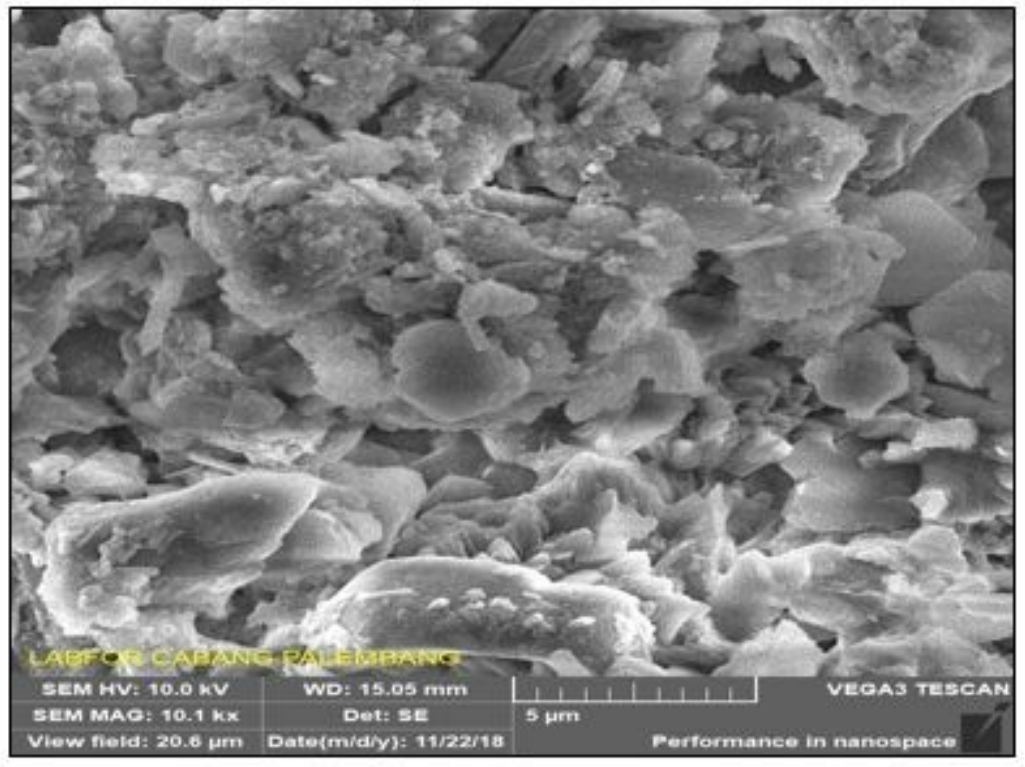

$7 \mathrm{~b}$

Figure 7

7a. Scanning electron microscope image of CCR before pretreatment at magnification of $10.1 \mathrm{kx} 7 \mathrm{~b}$. Scanning electron microscope image of CCR after pretreatment at magnification of $10.1 \mathrm{kx}$ 


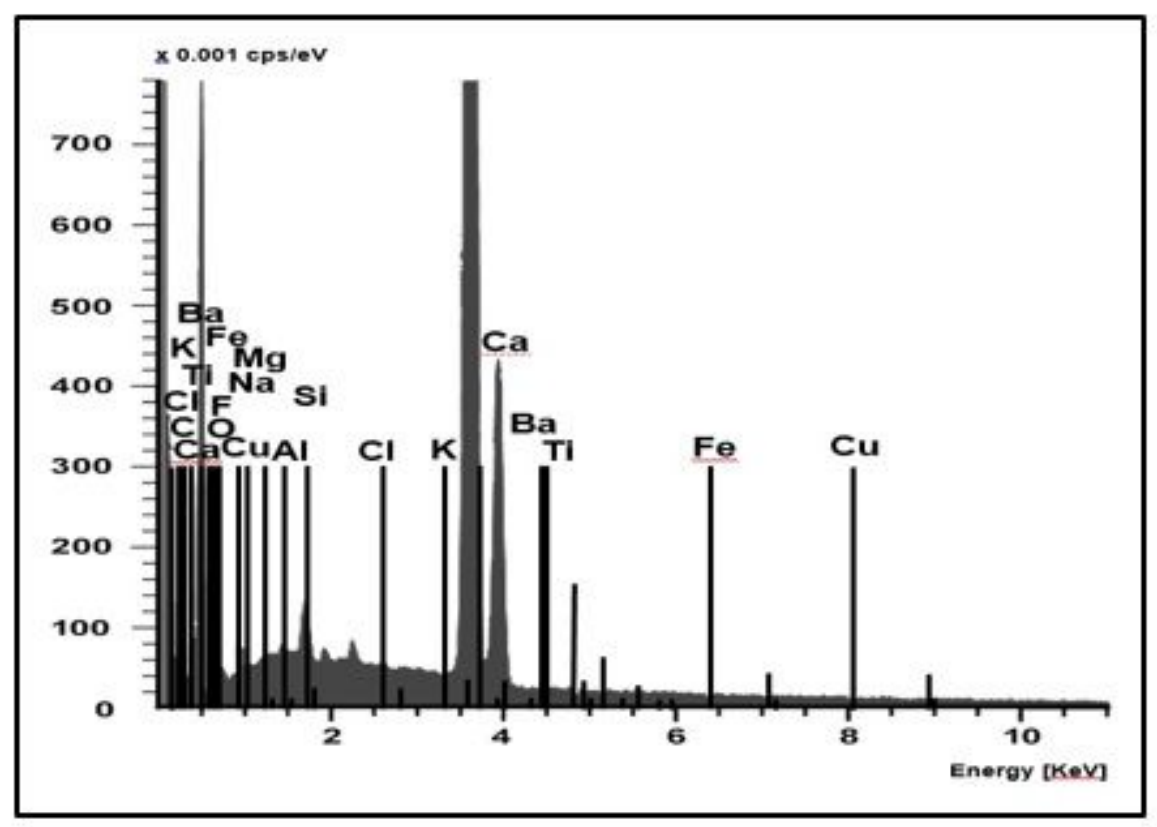

8a.

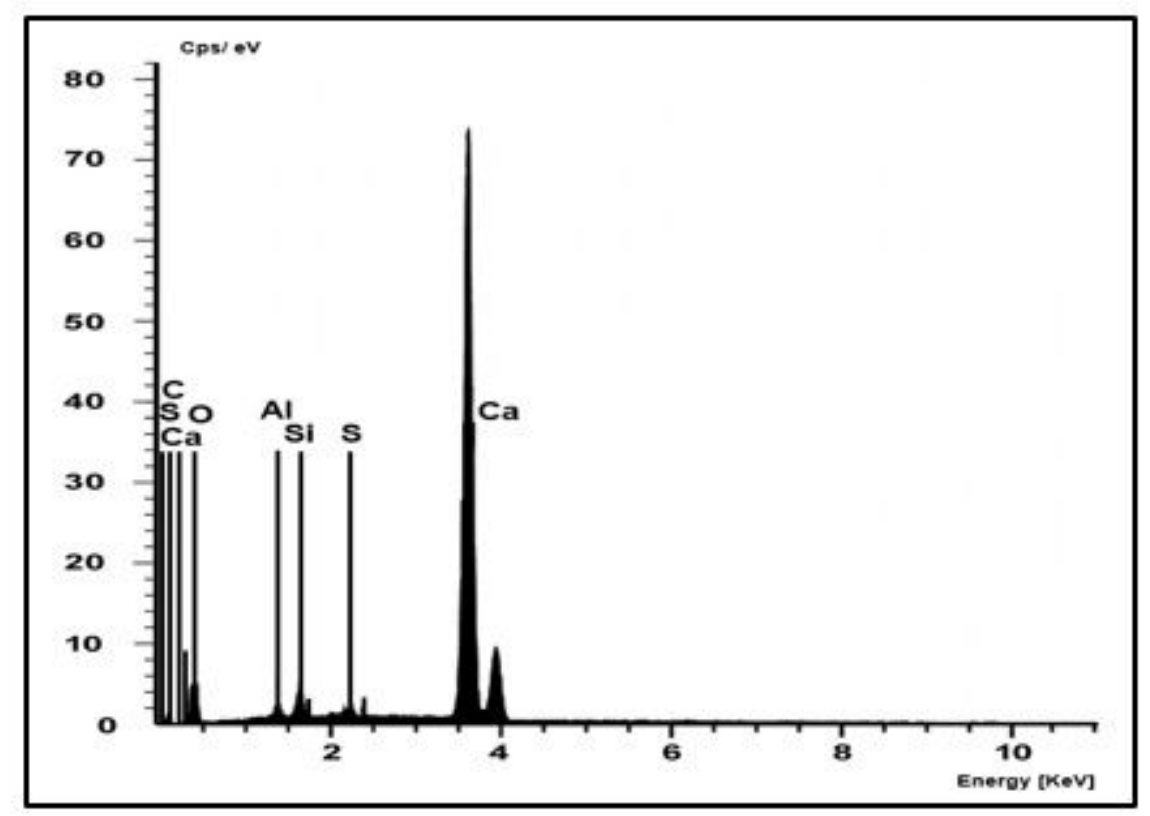

8b.

Figure 8

8a. CCR spectra EDS before pretreatment 8b. CCR spectra EDS after pretreatment 


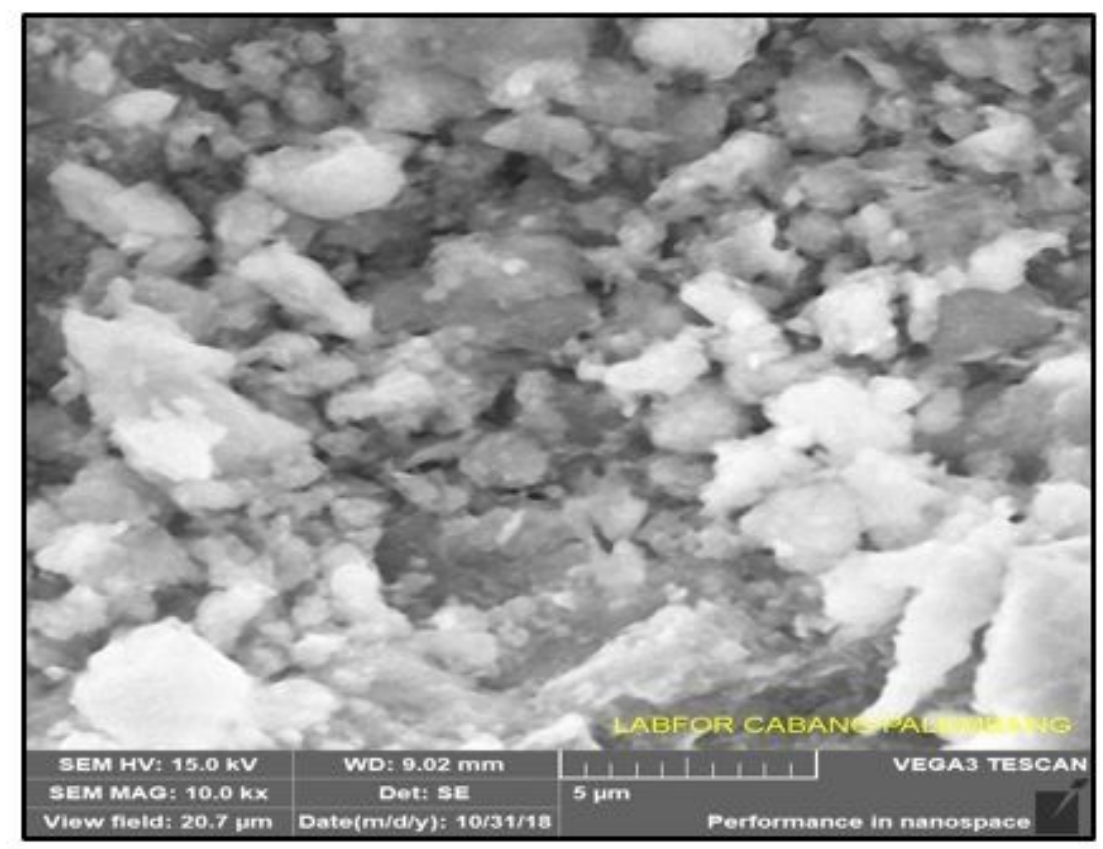

\section{$9 a$}

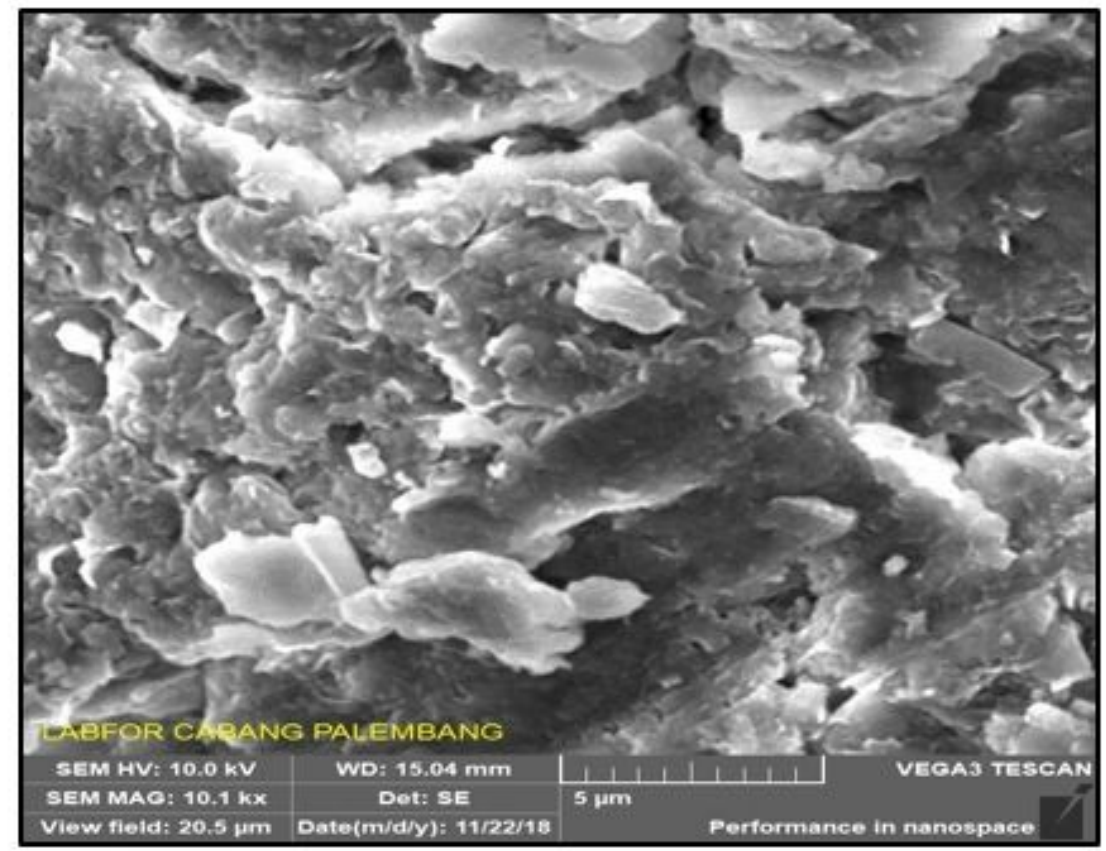

$9 \mathrm{~b}$

Figure 9

9 a. Scanning electron microscope image of Bentonite before pretreatment at magnification of $10.0 \mathrm{kx} 9 \mathrm{~b}$. Scanning electron microscope image of Bentonite after pretreatment at magnification of $10.1 \mathrm{kx}$ 


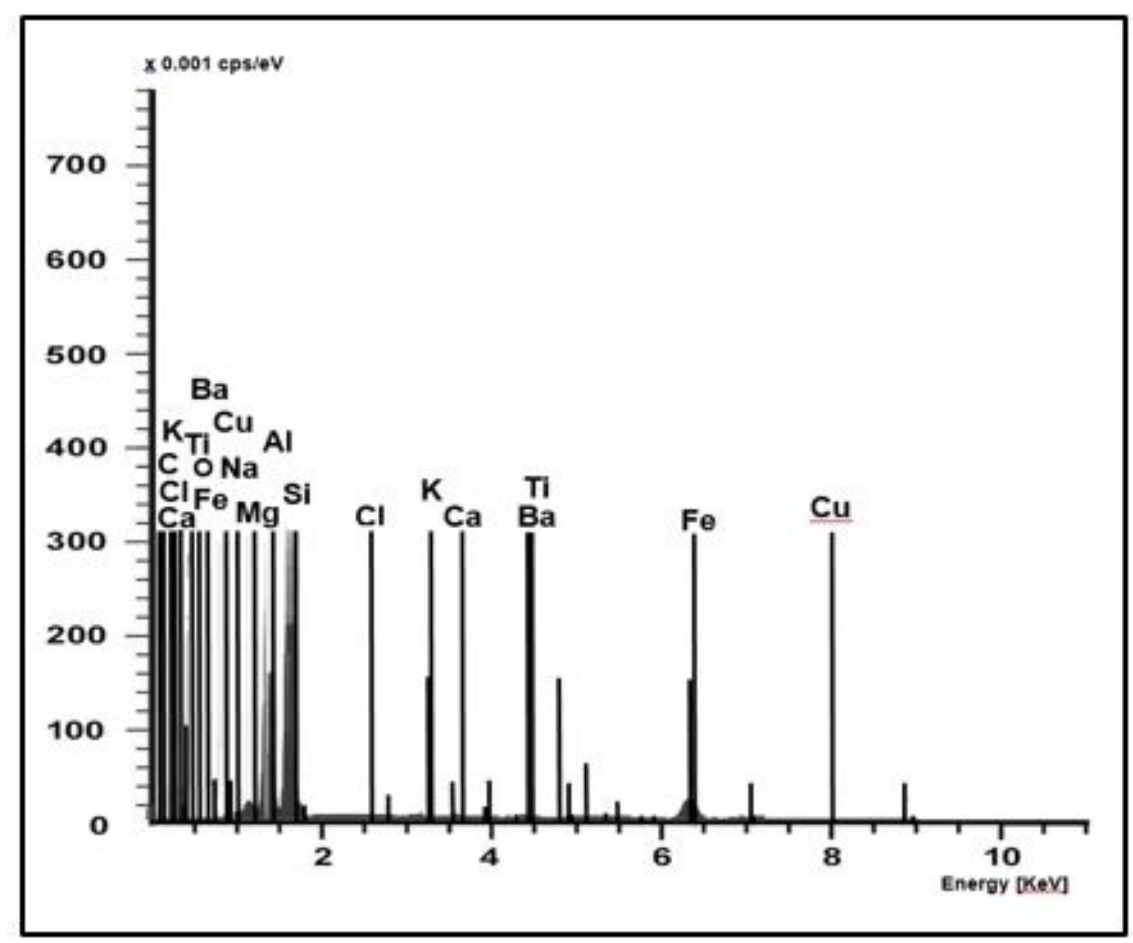

$10 a$

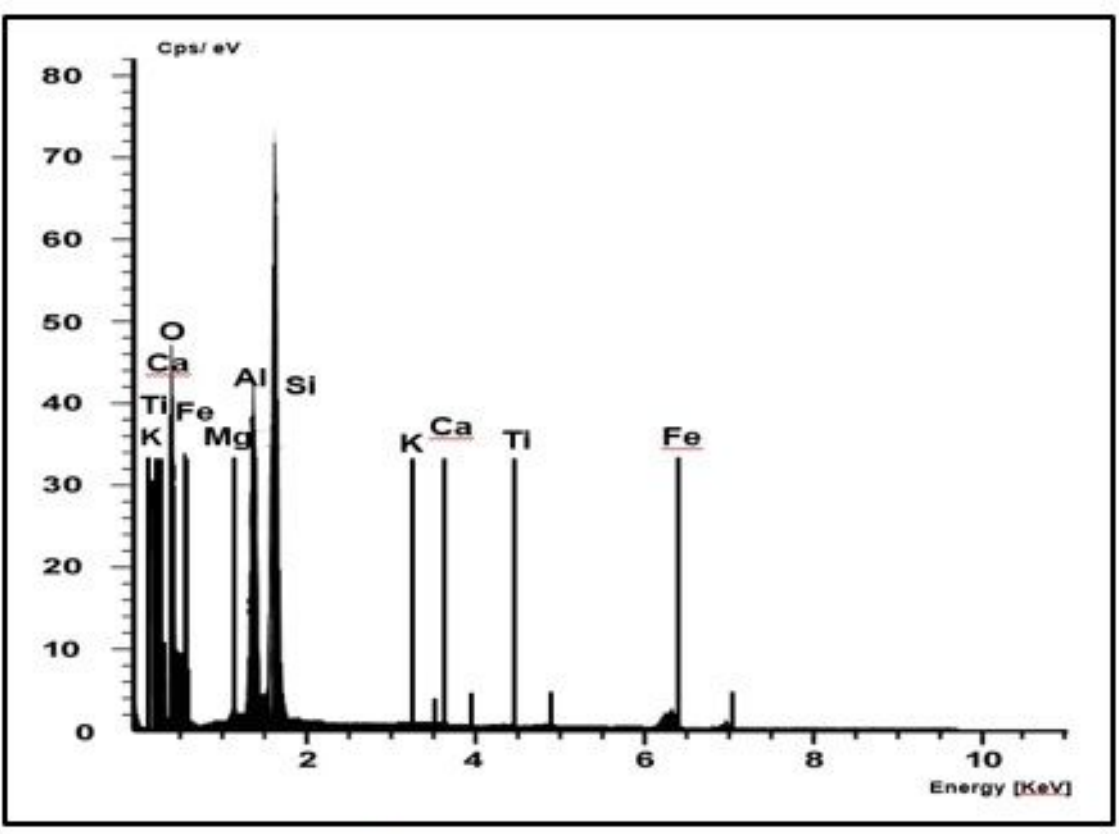

$10 \mathrm{~b}$

Figure 10

10a. Bentonite spectra EDS before pretreatment 10b. Bentonite spectra EDS after pretreatment 


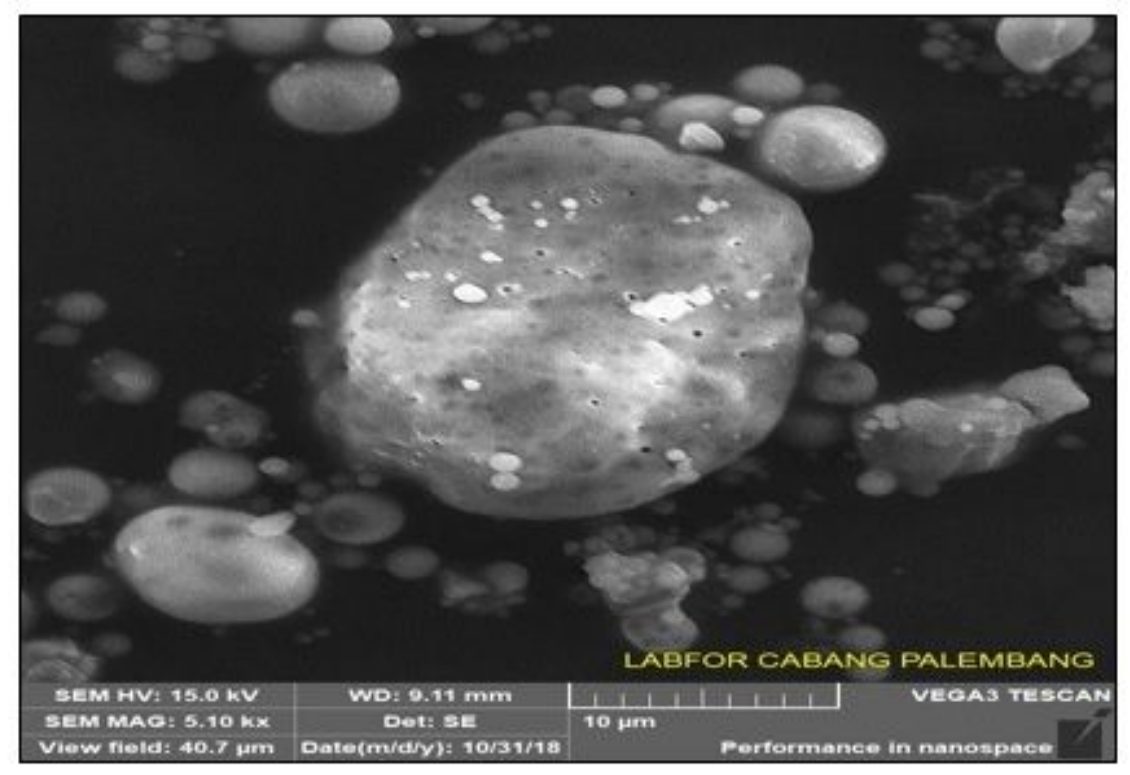

\section{$11 a$}

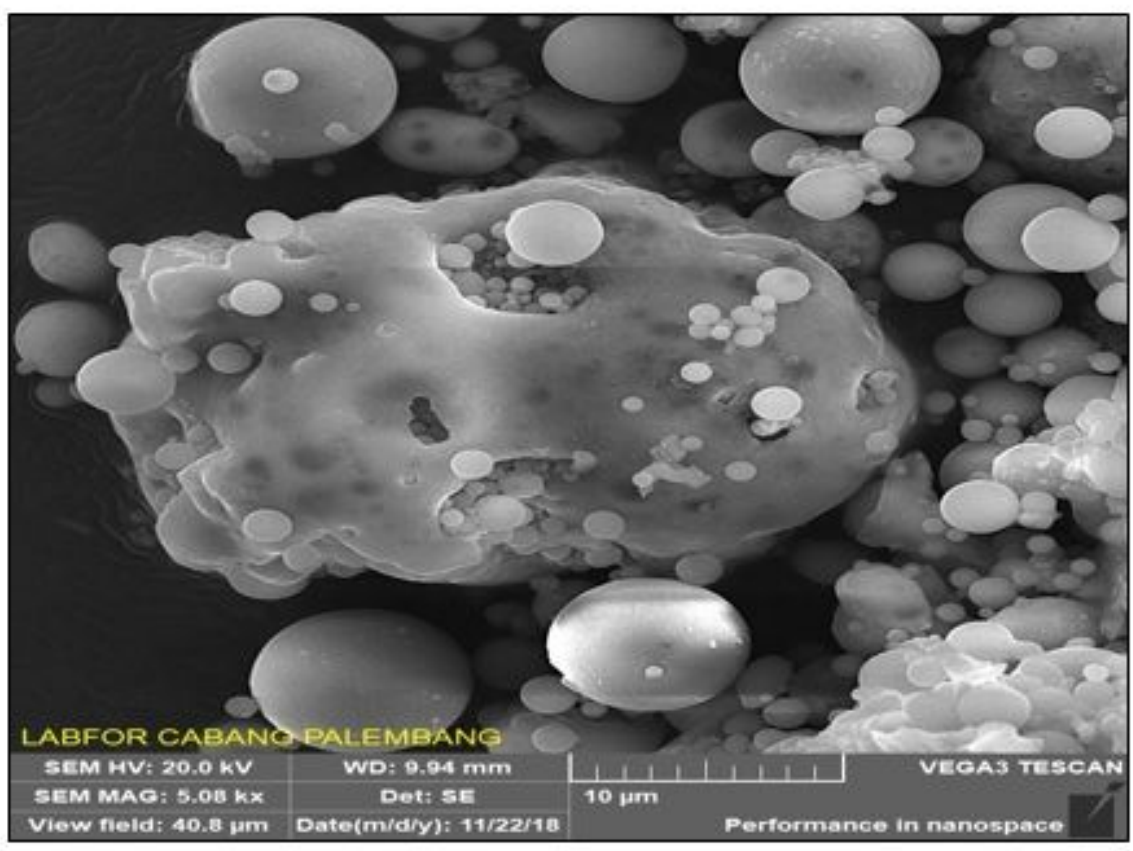

$11 b$

\section{Figure 11}

11a. Scanning electron microscope image of Fly Ash before pretreatment at magnification of 5.10kx 11b. Scanning electron microscope image of Fly Ash after pretreatment at magnification of $5.08 \mathrm{kx}$ 


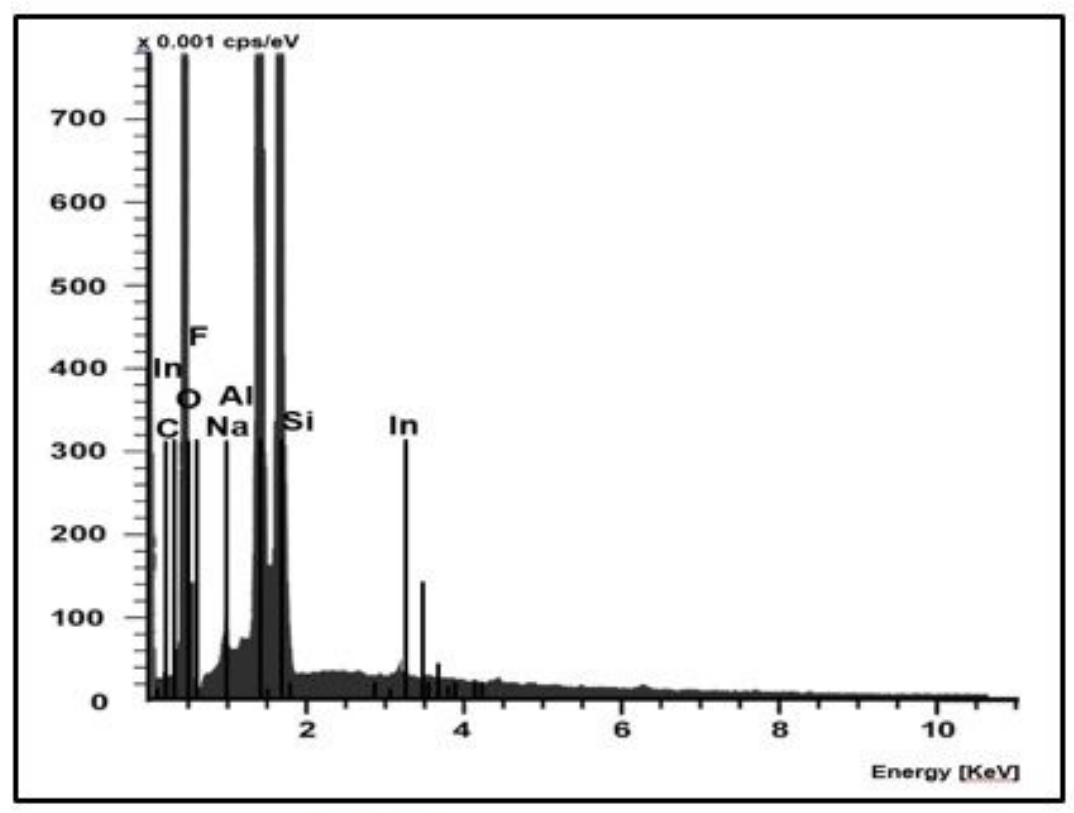

$12 a$

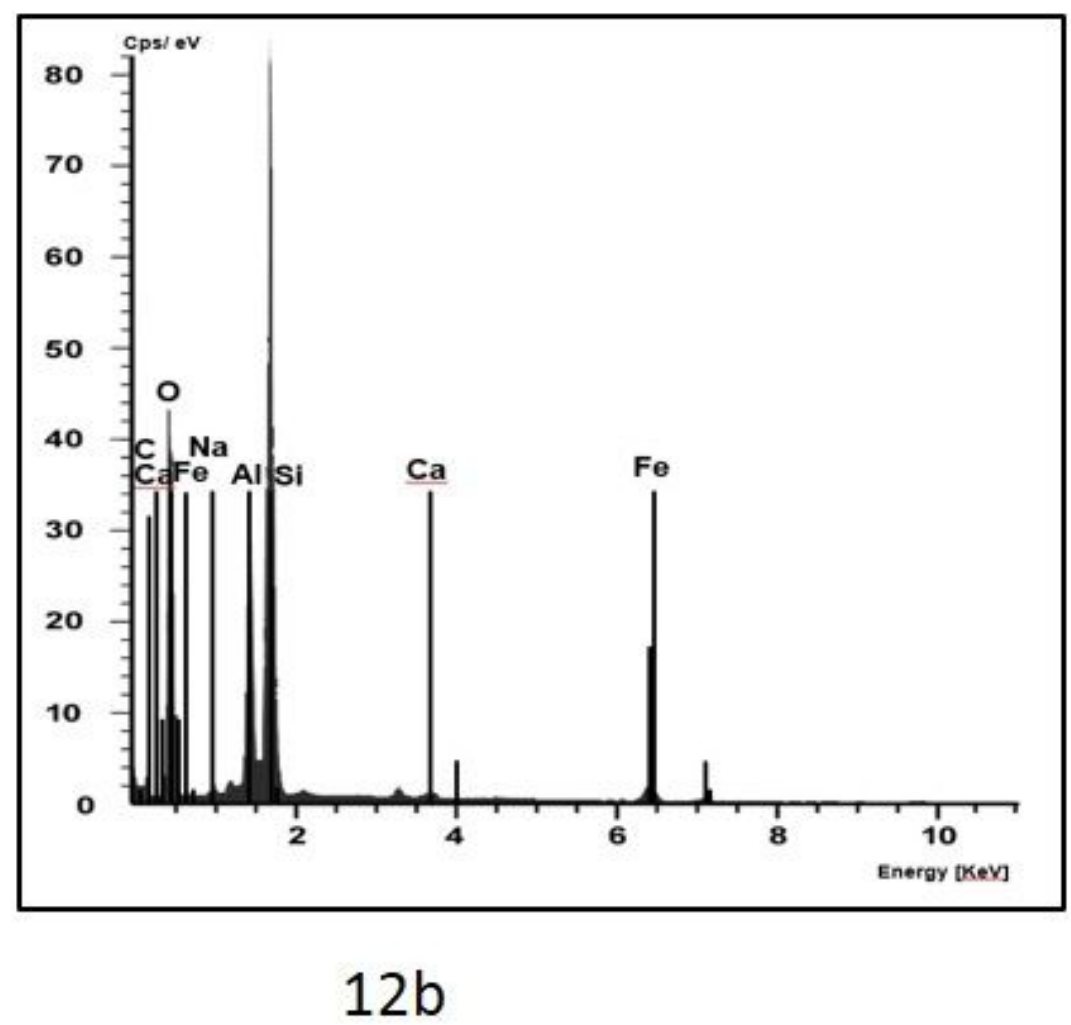

Figure 12

12a. Fly Ash Spectra EDS before pretreatment 12 b. Fly Ash Spectra EDS after pretreatment 